\title{
Age, CEO Succession, and Risk Taking
}

\author{
Eahab Elsaid \\ Associate Professor of Finance \\ Odette School of Business \\ University of Windsor, Canada \\ E-mail: eahabmk@hotmail.com \\ Nancy D Ursel \\ Professor of Finance \\ Odette School of Business \\ University of Windsor, Canada \\ E-mail: ursel@uwindsor.ca
}

Received: August 9, 2012

Accepted: August 23, 2012

Online Published: August 27, 2012

doi:10.5430/afr.v1n2p77

URL: http://dx.doi.org/10.5430/afr.v1n2p77

\begin{abstract}
CEO successions are major corporate events with the potential to change corporate direction. We investigate risk-taking following CEO succession and whether age affects CEO succession. In 679 CEO successions occurring between 1992 and 2005 in 650 small, medium and large-cap North American firms, we find that, except when the predecessor CEO was forced to leave, successor CEOs tend to entrench the status quo in terms of age. Board age has implications for corporate risk taking, with older boards being associated with less firm risk taking.
\end{abstract}

Keywords: CEO succession, $\mathrm{CEO}$ age, Corporate risk management, Board age

\section{Introduction}

There is a substantial body of literature regarding the antecedents and consequences of CEO succession. In terms of antecedents, there has been much focus on the effect of inside versus outside directors on CEO choice (Borokhovich et al. 1996) and on the similarity of CEO candidates to the members of the Board of Directors (Zajac and Westphal 1996). Consequences of CEO succession that have been studied include divestitures (Weisbach 1995) and the corporate investment decision (Goel and Thakor 2008).

We address gaps in the existing literature on $\mathrm{CEO}$ succession by examining additional antecedents and consequences of CEO succession. In terms of antecedents, we study the impact of the age of the Board on CEO choice. After reviewing the CEO succession literature, Brickley (2003) argues that "the turnover/age relation has the potential to provide important insights on CEO turnover." Populations and workforces around the world are ageing (United Nations 2002, 2007), so understanding the implications of age is critical. In terms of consequences, we investigate what impact $\mathrm{CEO}$ choice has for corporate risk management. Our focus on these variables is motivated by findings that are well-supported in the literature. First, numerous studies have shown a link between demographic characteristics and risk taking. Second, it is widely agreed that inadequate risk management was a major cause of the recent global financial crisis (Power 2009; Economist Intelligence Unit 2009). Thus overall our study shows if the age of those in governance positions affects the risk profile they chose for the firm, and whether the Board appoints as CEO individuals who are similar to themselves in age. In short, we examine whether CEO successions are truly opportunities for change in corporate risk taking practices or whether risk management ideas become entrenched within corporations. Although many studies of board demographics already exist, most focus on the effect of demographics on firm performance (Davidson et al. 2006). We are among the first to focus on corporate risk management. 


\section{Demographics, risk taking and succession}

\subsection{Age and risk taking}

Age has been demonstrated to affect personal risk taking in general and more specifically corporate risk taking. Many studies use investors' portfolio choices to gauge willingness to take risk. Ackert et al. (2002) find older investors hold a lower percentage of their risky assets in equities, as compared to bonds, consistent with increasing risk aversion with age. Similarly, Bodie and Crane (1997) and Morin and Suarez (1983) find age significantly negatively related to percentage of risky assets held in equity. Samanez-Larkin et al. (2010) find unique effects of age on risk taking in financial decision making.

Vroom and Pahl (1971) study risk taking by managers. Using a questionnaire administered to managers, these authors found older managers were more risk averse. In a corporate setting, Wiersema and Bantel (1992) find that the firms most likely to undergo changes in corporate strategy have top management teams characterized by lower average age. This might also be interpreted as risk aversion increasing with age. We investigate if a change in CEO age due to succession results in the adoption of a new risk profile for the firm.

\subsection{Hiring people like yourself}

There has been considerable previous research on the concept of similarity-attraction that covers both the management and organizational behaviour literature (e.g., Tsui and O'Reilly 1989; Judge and Ferris 1993) and the psychology literature (e.g., Jackson et al. 1991). Schneider (1987) developed the attraction-selection-attrition model which suggests that firms evolved towards interpersonal homogeneity. Pfeffer (1983) developed the organizational demography model which suggests that the organization's demographic composition affects its structure and communication patterns. The board may see the age similarity with the CEO as a basis for a relationship with the successor and as an indication that they have a similar mindset in approaching problems. Wagner, Pfeffer and O'Reilly (1984) find that age dissimilarity increases managerial turnover in firms.

Wenzel (2001) invokes social categorization theory (Tajfel 1982) to explain how individuals decide which applicants are most deserving of a position within their organization. He finds that individuals judge their own characteristics to be especially salient selection criteria and select applicants who display similar attributes. Szafarz (2007) presents an alternative method of modelling such affinity based hiring.

Westphal and Zajac (1995) provide support for such theories in a corporate setting, finding that new directors are demographically similar to the person (CEO) or group (board of directors) that was primarily responsible for appointing them. We test whether this holds in reverse: are new CEOs similar in age to the boards that appoint them?

\subsection{CEO successions}

Although in theory boards of directors choose the CEO, Hermalin and Weisbach (2003) and Denis and Sarin (1999) show that in reality, the process is not so clear-cut. Westphal and Zajac (1995) find that the more powerful party between the CEO and the board gets to choose new board members who are demographically similar. Zajac and Westphal (1996) find that powerful boards appoint a demographically similar CEO, especially when the CEO is an outsider. Borokhovic et al. (1996) find that firms with more outside directors are more likely to appoint an outside CEO.

Large changes in board membership typically occur at the time of CEO succession, and whether the CEO or the board is driving the changes is influenced by many factors related to their relative power. Among the factors that influence the relative power of the CEO and the board are whether the successor CEO is a designated heir, whether the predecessor CEO was forced to leave, and whether the successor CEO comes from inside or outside the firm (Worrell et al. 1997; Elsaid and Davidson 2009; Davidson et al. 2008). We include variables representing these factors in our analysis.

Additionally, because it is not clear whether the CEO or the board is mainly responsible for choosing the successor $\mathrm{CEO}$, we do not model CEO succession as a function of the pre-succession characteristics of the board. Instead, we examine the changes in the board contemporaneous with the CEO succession.

\section{Hypotheses and empirical methodology}

We use regression analysis to examine the effect of age on CEO succession and risk taking. Hypothesis 1 directly addresses a question Brickley (2003) notes is important but unresolved: "Is the age of a prospective candidate an important consideration in the selection of a new CEO?" (Brickley 2003, p. 232). 
Hypothesis 1: The change in age of the $\mathrm{CEO}$ arising from succession is a positive function of the change in average age of the board (i.e., H1: $\alpha_{1}>0$ in the following expression):

$\Delta$ CEO age $=\alpha_{0}+\alpha_{1} \Delta$ average age of board $+\delta \mathrm{x}+\varepsilon(1)$

Where: $\Delta \mathrm{CEO}$ age and $\Delta$ average age of board are measured variables;

$\alpha_{0}, \alpha_{1}$ and $\alpha_{2}$ are regression coefficients;

$\delta$ is a vector of regression coefficients;

$\mathrm{x}$ is a vector of control variables; and

$\varepsilon$ is an error term.

Hypothesis 2: The change in riskiness of a corporation following CEO succession is a negative function of the change in CEO age (i.e., $\mathrm{H} 2: \alpha_{1}<0$ in the following expression):

$\Delta$ corporate risk $=\alpha_{0}+\alpha_{1} \Delta \mathrm{CEO}$ age $+\delta \mathrm{x}+\varepsilon(2)$

We recognize the endogeneity of risk taking, age and average board age: While CEO age may affect corporate risk taking, as hypothesized in hypothesis 2 , it may also be true that firms with particular risk profiles are more inclined to choose specific ages of CEO and ages of boards. Similarly, there may be endogenous effects that make firms that choose older CEOs also more likely to hire older boards, as in hypotheses 1 . Because such endogeneity can cause bias in ordinary least squares (OLS) regression, we employ two stage least squares regression (2SLS).

For stage 1 of hypothesis 1 , we use the following instrumental variable to model the change in average board age: the average age of newly appointed directors in the year of succession (using data from the Roster of New Director Appointments in appropriate issues of Directors and Boards). For stage 1 of hypothesis 2, we estimate the change in CEO age with the instrumental variable: average age of Fortune 500 CEOs. These variables meet the requirements of instrumental variables in that they are related to the choice of CEO but not related to the error term. In the tables we show the findings for the 2SLS regressions.

We include dummy variables to represent the year of the CEO succession. Timing will be important to the extent that firms increasingly choose younger CEOs and younger board members over the sample period.

\section{Data sources and variable definitions}

We form our sample by searching Standard and Poor's Execucomp database for CEO successions. Execucomp contains data about top executives and their compensation for large, small and mid cap North American firms. We exclude financial firms (SIC 6020-6799), consistent with Alexander (2006) and others who find that corporate governance in financial institutions is very different than in non-financial firms. Between 1992 and 2005 we find 758 CEO successions. We use these firms' proxy statements to obtain data such as the average age of directors and whether the successor CEO is an insider or outsider. We obtain financial statement information from Compustat. We exclude all successions where board membership does not change from before to after succession. We do this to avoid having the measure of change in board age act as a proxy for board stability. This reduces our sample size to 679 CEO successions in 650 firms.

The dependent variable for hypothesis 1 is the difference between the age of the CEO post and pre succession. The dependent variable in hypothesis 2 is the change in the risk profile of the firm from pre to post CEO succession. We look at change in risk over three periods relative to the succession, which we can think of as occurring in year " 0 ". The three periods we examine are year -1 to year +1 ; year -3 to year +3 and year -5 to year +5 . All three periods produce similar results, although the year -1 to year +1 findings are somewhat less significant, perhaps because new CEOs do not have time to effectively implement their plans over this short horizon. We present the year -3 to year +3 findings in the tables of this paper. We use the standard deviation of cash flows adjusted for sector average standard deviation (as in John et al., 2008) as the measure of corporate riskiness (Note 1). The principal independent variables are as follows: the change in the average age of the board (hypothesis 1) and the change in the age of the CEO (hypothesis 2).

To control for other factors which may influence the hypothesized relationships, we include the following control variables in each equation:

i) Firm size: To control for possible size-related heteroscedasticity and because large and small firms may behave differently, we include a variable representing firm size. We measure this variable as the natural logarithm of the aggregate of the firm's total assets from years -3 to -1 relative to CEO succession. 
ii) Profitability: As in Carter, Simkins and Simpson (2003) we include return on assets (ROA) as a control variable in our regression equations. We create an industry adjusted ROA measure (Barber and Lyon, 1996) for each firm for years -3 to -1 relative to succession. We computed the industry adjusted ROA by subtracting the firm's average industry ROA (using four digit SIC codes where possible and three digit SIC codes when there are not at least three other firms in the same four digit SIC code) from each individual firm's ROA. We obtain data for this measure from Compustat.

iii) Forced versus voluntary succession: To determine the type of succession, we examine Wall Street Journal Index (WSJI) and the Wall Street Journal (WSJ) for the reasons for the successions. From the news stories, we classify forced successions as all CEO successions other than those arising from retirement, death, illness, or those involving the CEO's departure for a better and more prestigious position in another firm. As in Parrino (1997), we consider retirements of CEOs before the age of 60 to be forced retirements. We code the variable as a 1 for forced turnover and 0 otherwise.

iv) Designated heir: Some firms have formal succession plans (Behn et al., 2005; Shen and Cannella, 2003). We use the approaches in Vancil (1987), Kesner and Sebora (1994), Zhang and Rajagopalan (2006) and Dalton and Kesner (1983) to determine if our sample firms have a succession plan. The existence of such plans obviously impacts CEO succession, so we include a dummy variable with a value of 1 when there is an heir apparent as defined in Shen and Cannella, zero otherwise.

v) Inside versus outside successor: If the board hires a CEO from inside the

firm, we classify this as an inside successor and code the dummy variable as 1 for this case. We code outsiders as a 0. Consistent with Naveen (2006) we consider CEOs who have been with the firm less than one year before being appointed to the CEO position to be outsiders. However, to remove interim CEOs from the sample, we discard observations for CEOs with a tenure of 1.5 years or less in the CEO position.

vi) Dummy variables representing the year of succession are included to capture the fact that firms have started to increasingly hire younger CEOs and board members over time. For ease of presentation, we do not show their estimated coefficients in the tables.

When testing the hypothesis concerning risk taking (hypothesis 2) we include two additional control variables as follows:

vii) A variable "CEO horizon" to reflect the possibility (Dechow and Sloan 1991) that CEOs with short expected careers due to imminent retirement may reduce $R \& D$ expenditures to improve near term earnings reports. We calculate this variable as 65 less the age of the new CEO, which we obtain from Execucomp. When the CEO is older than 65, we use zero for this variable. Sixty five is the usual retirement age for CEOs (Wright et al., 2007).

viii) Change in CEO's "pay at risk" over the succession period: We measure pay at risk as the proportion of bonuses, restricted stock grants and option grants (excluding reloads) to total compensation less bonuses, restricted stock and option grants, using data from Execucomp (Elsaid and Davidson 2009). Firms use such incentive compensation to manage managerial risk taking and align the interests of managers and shareholders (Beatty and Zajac, 1994; Ryan and Wiggins, 2002; Yermack, 1997; Yermack and Ofek, 2000). In our study of managerial risk taking, we thought it important to control for firms' attempts to manage this variable.

\section{Empirical findings}

\section{Insert Table 1 About Here}

Table 1 presents the 2SLS estimates of the relation between the change in age of the CEO and the change in the average age of the board members. The 2SLS results show that the coefficient of the variable for change in average board age is significant at the $0.1 \%$ level and has the expected sign, i.e., older CEOs are accompanied by older boards. Two other variables are significant in this equation: the dummy variable indicating whether the CEO succession was a forced turnover and the dummy variable indicating whether the new CEO is from inside or outside the firm. The sign of the forced turnover variable is positive, indicating that in situations where the predecessor CEO is forced to resign, the successor CEO tends to be older than the predecessor. This is consistent with firms seeking older and therefore presumably more experienced leaders in times of corporate difficulty and turmoil. The sign of the inside successor variable is also significantly different from zero. The sign is negative, consistent with the notion that older successor 
CEOs tend to be appointments from outside the firm. These findings confirm Brickley's (2003) intuition that the age of the CEO is related to the form of succession.

\section{Insert Table 2 About Here}

Table 2 presents the 2SLS estimates of the relation between the corporate risk measure (the standard deviation of cash flows adjusted for sector average standard deviation) and the change in CEO age. The 2SLS results show that the change in the CEO age is statistically significant for the corporate risk measure. In the regression, the sign of the relation between the risk measure and the change in CEO age is negative as predicted by hypothesis 2 . This is consistent with older CEOs being associated with less risk-taking by the firm. The profitability (measured as industry adjusted ROA) control variable also has a negative significant impact on risk taking. The White-Koenker statistics given in the last line of the Tables 1 and 2 show that all of our regressions are free of heteroscedasticity (Baum et al., 2002).

\section{Concluding remarks}

CEO successions are significant events for firms and potential opportunities for significant change in corporate direction. We study CEO successions to determine if the age variable plays an important role in CEO choice or in the effects of CEO succession.

In terms of CEO choice, age is important: successor CEOs tend to resemble their boards in terms of age. This finding is consistent with the Pfeffer (1983), Schneider (1987), Wenzel (2001) and the Westphal and Zajac's (1995) work and illustrates the tendency for individuals to "hire people like themselves". In view of this finding, it is possible that CEO succession serves more to entrench the status quo in a firm rather than provide an opportunity for true corporate change and renewal.

In one situation companies clearly depart from this entrenchment scenario. When the predecessor CEO has been forced to resign, successor CEOs differ significantly from the predecessor in age. In these situations, successor CEOs are significantly older than their predecessors and presumably bring more managerial experience to the firm at a time when it is likely to need improved management. This finding suggests firms are making reasonable CEO succession decisions, maintaining stability when the firm is operating well and making substantial change when required, although more data would be required before an unequivocal statement could be made.

We find that changes in CEO age also have significant effects on corporate risk taking, in line with hypothesis 2. Consistent with much past literature on age and risk taking (e.g., Ackert et al., 2002; Barber and Odean, 2001), we find measures of corporate risk taking decline when the average $\mathrm{CEO}$ age increases with succession. This decrease in risk taking was observed despite inclusion of a control variable representing pay at risk and CEO horizon.

\subsection{Implications}

The implications of these findings for research and practice are as follows: Researchers studying other antecedents and consequences of CEO succession should include the demographic variables such as age in their studies, since it is a significant variable. Firms wishing to control risk should ensure appropriate representation of older directors on the board, as the presence of older directors on the board is positively related to the appointment of older CEOs, who we show to be associated with reduced risk taking.

\subsection{Limitations}

One of the limitations for our research is that the sample was based on North American firms, thus it inevitably reflects a specific national culture's age orientations. To complement this limitation, the inclusion of firms and managers from diverse national-cultural backgrounds would potentially add important insights to age and its relation to risk taking. We believe that in addition to age, national culture may have an effect on risk taking behaviour. Another limitation for our data is that it does not include privately held firms. Both Execucomp and Compustat only include publicly traded firms and privately held firms do not have publicly available proxy statements.

\section{Recommendations for future research}

Because the 1990s and early 2000s were a period of high and perhaps excessive risk taking which resulted in a massive global financial crisis, future research should address different demographic variables that affect risk-taking behaviour. There are long standing stereotypes of female risk aversion. Do female CEOs take less risk than their male counterparts? Does having a larger number of female directors on the board of directors increase the probability of hiring a female $\mathrm{CEO}$ and thus taking on less risk? Another interesting area for future research is how ethnicity, religion, cultural background and socio-economic position of the $\mathrm{CEO}$ and the members of the board of directors influence not only the individual risk-taking behaviour, but also that of the firms. 
Another direction for future research would be to address whether boards that hire demographically similar CEOs increase firm performance and CEO tenure. In addition, future research could address whether demographic similarity between boards and CEOs helps in increasing job satisfaction for the CEOs.

\section{References}

Ackert, L., Church, B., \& Englis, B. (2002). The asset allocation decision and investor heterogeneity: A puzzle? Journal of Economic Behavior and Organization, 47 (4), 423-433. http://dx.doi.org/10.1016/S0167-2681(01)00209-8

Alexander, K. (2006). Corporate governance and banks: The role of regulation in reducing the principal-agent problem. Journal of Banking Regulation, 7 (1/2), 17-40.

Barber, B., \& Odean, T. (2001). Boys will be boys: Gender, overconfidence and common stock investment. Quarterly Journal of Economics, 116 (1), 261-292. http://dx.doi.org/ 10.1162/003355301556400

Barber, B., \& Lyon, J. (1996). Detecting abnormal operating performance: The empirical power and specification of test statistics. Journal of Financial Economics, 41 (3), 359- 399. http://dx.doi.org/10.1016/0304-405X(96)84701-5

Baum, C., Schaffer, M., \& Stillman, S. (2002). Instrumental variables and GMM: Estimation and testing. Unpublished manuscript, Boston College, Boston, MA.

[Online] Available: http://www.cba.ua.edu/assets/docs/jlee/ec671/ivgmm_stata.pdf (August 1, 2012)

Beatty, R., \& Zajac, E. (1994). Managerial incentives, monitoring and risk bearing: A study of executive compensation, ownership, and board structure in initial public offerings. Administrative Science Quarterly, 39 (2), 313-335.

Behn, B. K., Riley, R. A., \& Yang, Y. (2005). The value of an heir apparent in succession planning. Corporate Governance: An International Review, 13 (2), 168-177. http://dx.doi.org/10.1111/j.1467-8683.2005.00415.x

Bodie, Z., \& Crane, D. (1997). Personal investing advice, theory, and evidence. Financial Analysts Journal, 53 (6), 13-23.

Borokhovich, K., Parrino, R., \& Trapani, T. (1996). Outside directors and CEO selection. Journal of Financial and Quantitative Analysis, 31 (3), 337-355.

Brickley, J. (2003). Empirical research on CEO turnover and firm performance: A discussion. Journal of Accounting and Economics, 36 (1-3), 227-233. http://dx.doi.org/10.1016/j.jacceco.2003.09.003

Carter, D., Simkins, B., \& Simpson, W. (2003). Corporate governance, board diversity and firm value. The Financial Review, 38 (1), 33-53. http://dx.doi.org/10.1111/1540-6288.00034

Chan, L., Lakonishok, J., \& Sougiannis, T. (2001). The stock market valuation of research and development expenditures. Journal of Finance, 56 (6), 2431-2456. http://dx.doi.org/10.1111/0022-1082.00411

Dalton, D., \& Kesner, I. (1983). Inside/outside succession and organizational size: The pragmatics of executive replacement. Academy of Management Journal, 26 (4), 736-742. http://dx.doi.org/10.2307/255919

Davidson, W., Nemec, C., \& Worrell, D. (2006). Determinants of CEO age at Succession. Journal of Management and Governance, 10 (1), 35-57. http://dx.doi.org/ 10.1007/s10997-005-3548-5

Davidson, W., Ning, Y., Rakowski, D., \& Elsaid, E. (2008). The antecedents of simultaneous appointments to CEO and Chair. Journal of Management and Governance, 12 (4), 381-401. http://dx.doi.org/ 10.1007/s10997-008-9066-5

Dechow, P., \& Sloan, R. (1991). Executive incentives and the horizon problem: An empirical investigation. Journal of Accounting and Economics, 14 (1), 51-90. http://dx.doi.org/10.1016/0167-7187(91)90058-S

Denis, D., \& Sarin, A. (1999). Ownership and board structures in publicly traded corporations. Journal of Financial Economics, 52 (2), 187-223. http://dx.doi.org/ 10.1016/S0304-405X(99)00008-2

Economist Intelligence Unit, (2009). Managing Risk in Perilous Times: Practical Steps to Accelerate Recovery. [Online] Available: http://viewswire.eiu.com/report_dl.asp?mode=fi\&fi=564382841.PDF (August 1, 2012)

Elsaid, E., \& Davidson, W. (2009). What happens to CEO compensation following turnover and succession? Quarterly Review of Economics and Finance, 49 (2), 424-447. http://dx.doi.org/10.1016/j.qref.2008.04.001

Goel, A., \& Thakor, A. (2008). Overconfidence, CEO selection and corporate governance. Journal of Finance, 63 (6), 2737-2748. http://dx.doi.org/10.1111/j.1540-6261.2008.01412.x 
Guney, Y., Ozcan, A., \& Ozcan, N. (2007). International evidence on the non-linear impact of leverage on corporate cash holdings. Journal of Multinational Financial Management. 17 (1), 45-60. http://dx.doi.org/10.1016/j.mulfin.2006.03.003

Haugen, R., \& Senbet, L. (1981). Resolving the agency problems of external capital through options. Journal of Finance, 36 (3), 629-647.

Hermalin, B., \& Weisbach, M. (2003). Boards of directors as an endogenously determined institution: A survey of the economic literature. Economic Policy Review, 9 (1), 7-26.

Jackson, S., Brett, J., Sessa, V., Cooper, D., Julin, J., \& Peyronnin, K. (1991). Some differences make a difference: Interpersonal dissimilarity and group heterogeneity as correlates of recruitment, promotion, and turnover. Journal of Applied Psychology, 76 (5), 675-689. http://dx.doi.org/10.1037/0021-9010.76.5.675

John, K., Litov, L., \& Yeung, B. (2008). Corporate governance and risk-taking. Journal of Finance. 63 (4), 1679-1728. http://dx.doi.org/10.1111/j.1540-6261.2008.01372.x

Judge, T., \& Ferris, G. (1993). Social context of performance evaluation decisions. Academy of Management Journal, 36 (1), 80-105. http://dx.doi.org/10.2307/256513

Kesner, I., \& Sebora, T. (1994). Executive succession: Past, present and future. Journal of Management, 20 (2), 327-372. http://dx.doi.org/10.1016/0149-2063(94)90019-1

Morin, R., \& Suarez, A. (1983). Risk aversion revisited. Journal of Finance, 38 (4), 1201-1216. http://dx.doi.org/10.2307/2328020

Nam, J., Ottoo, R., \& Thornton, J. (2003). The effect of managerial incentives to bear risk on corporate capital structure and R\&D investment. The Financial Review, 38 (1), 77-101. http://dx.doi.org/10.1111/1540-6288.00036

Naveen, L. (2006). Organizational complexity and succession planning. Journal of Financial and Quantitative Analysis, 41 (3), 661-683.

Parrino, R. (1997). CEO turnover and outside succession: A cross-sectional analysis. Journal of Financial Economics, 46 (2), 165-197. http://dx.doi.org/10.1016/S0304-405X(97)00028-7

Pfeffer, L. (1983). Organizational demography. In L. L. Cummings \& B. M. Staw (Eds.). Research in Organizational Behavior (pp. 299-357). Greenwich, CT: JAI press.

Power, M. (2009). The risk management of nothing. Accounting, Organizations and Society, 34 (6-7), 849-855. http://dx.doi.org/10.1016/j.aos.2009.06.001

Ryan, H., \& Wiggins, R. (2002). The interactions between R\&D investment decisions and compensation policy. Financial Management, 31, 5-29.

Samanez-Larkin, G., Kuhnen, C., Yoo, D., \& Knutson, B. (2010). Variability in nucleus accumbens activity mediates age-related suboptimal financial risk taking. Journal of Neuroscience, 30, 1426-1434.

Schneider, B. (1987). The people make the place. Personnel Psychology, 40 (3), 437-453.

Shen, W., \& Cannella, A. (2003). Will succession planning increase shareholder wealth? Evidence from investor reactions to relay CEO succession. Strategic Management Journal, 24 (2), 191-198. http://dx.doi.org/10.1002/smj.280

Smith, C., \& Watts, R .(1982). Incentive and tax effects of U.S. executive compensation plans. Australian Management Journal, 7 (1), 139-157.

Smith, C., \& Watts, R. (1992). The investment opportunity set and corporate financing, dividend and compensation policies. Journal of Financial Economics, 32 (3), 263-292. http://dx.doi.org/10.1016/0304-405X(92)90029-W

Szafarz, A. (2007). Hiring people-like-yourself: A representation of discrimination on the job market. Unpublished manuscript, Centre Emile Bernheim, Solvay Business School, Université Libre de Bruxelles, Brussels, Belgium. [Online] Available: http://dev.ulb.ac.be/dulbea/documents/1150.pdf (August 3, 2012).

Tajfel, H. (1982). Social Identity and Intergroup Relations. Cambridge: Cambridge University Press.

Tsui, A., \& O'Reilly, C. (1989). Beyond simple demographic effects: The importance of relational demography in superior-subordinate dyads. Academy of Management Journal, 32 (2), 402-423. http://dx.doi.org/10.2307/256368

United Nations, (2002). World Population Ageing: 1950-2050. New York: United Nations. [Online] Available: http://www.un.org/esa/population/publications/worldageing19502050/pdf/preface_web.pdf (August 3, 2012). 
United Nations, (2007). World Economic and Social Survey 2007: Development in an Ageing World. New York: United [Online] Available: http://www.un.org/en/development/desa/policy/wess/wess_archive/2007wess.pdf (August 5, 2012)

Vancil, R. (1987). Passing the baton: Managing the process of CEO Succession. Boston: Harvard Business School Press.

Vroom, V., \& Pahl, B. (1971). Relationship between age and risk taking among managers. Journal of Applied Psychology, 55 (5), 399-405. http://dx.doi.org/ 10.1037/h0031776

Weisbach, M .(1995). CEO turnover and the firm's investment decisions. Journal of Financial Economics, 37 (2), 159-188. http://dx.doi.org/10.1016/0304-405X(94)00793-Z

Wagner, W., Pfeffer, J., \& O'Reilly, C. (1984). Organization demography and turnover in top-management groups. Administrative Science Quarterly, 29 (1), 74-92.

Wenzel, M. (2001). A social categorization approach to distributive justice: Social identity as the link between relevance of inputs and need for justice. British Journal of Social Psychology, 40 (3), 315-335.

Westphal, J., \& Zajac, E. (1995). Who shall govern? CEO/board power, demographic similarity and new director selection. Administrative Science Quarterly, 40 (1), 60-83.

Wiersema, M., \& Bantel, K. (1992). Top management team demography and corporate strategic change. Academy of Management Journal, 35 (1), 91-121. http://dx.doi.org/10.2307/256474

Worrell, D., Nemec, C., \& Davidson, W. (1997). One hat too many: Key executive plurality and shareholder wealth. Strategic Management Journal, $18 \quad$ 499-507. http://dx.doi.org/10.1002/(SICI)1097-0266(199706)18:6<499::AID-SMJ898>3.0.CO;2-F

Wright, P., Kroll, M., Krug, J., \& Pettus, M. (2007). Influences of top management team incentives on firm risk taking. Strategic Management Journal, 28 (1), 81-89. http://dx.doi.org/10.1002/smj.548

Yermack, D. (1997). Good timing: CEO stock option awards and company news announcements. Journal of Finance, 52 (2), 449-476. http://dx.doi.org/10.2307/2329486

Yermack, D., \& Ofek, E. (2000). Taking stock: Equity-based compensation and the evolution of managerial ownership. Journal of Finance, 55 (3), 1367-1384. http://dx.doi.org/10.1111/0022-1082.00250

Zajac, E., \& Westphal, J. (1996). Who shall succeed? How CEO/board preferences affect the choice of new CEOs. Academy of Management Journal, 39 (1), 64-90. http://dx.doi.org/10.2307/256631

Zhang, Y., \& Rajagopalan, N. (2006). Grooming for the top post and ending the CEO succession crisis. Organizational Dynamics, 35 (1), 96-105. http://dx.doi.org/ 10.1016/j.orgdyn.2005.12.007

\section{Notes}

Note 1. In unreported work (available from the authors) we try other measures of risk as follows: financial leverage (as in Haugen and Senbet,1981; Smith and Watts, 1982 and 1992 and Nam et al., 2003), cash holdings as a percentage of total assets (as in Guney et al., 2007) - this is actually a measure of risk aversion, the degree of operating leverage, and research and development expenses as a percentage of sales (as in Nam et al. 2003). 
Table 1. 2SLS Estimates for Hypothesis 1: Change in age of the CEO is a positive function of the average age of the board ( $\mathrm{t}$ statistics in brackets)

\begin{tabular}{cc}
\hline & $\Delta$ CEO Age \\
\hline Constant & -12.954 \\
& $(-6.575)^{* * *}$ \\
Average Board Age & 0.411 \\
& $(3.724)^{* * *}$ \\
Ind. Adj. ROA ( $\mathrm{t}=-$ 3to-1) & 0.017 \\
& $(1.398)$ \\
Ln Total Assets ( $\mathrm{t}=-3$ to-1) & 0.285 \\
& $(1.317)$ \\
Designated Heir & -1.056 \\
Insider Successor & $(-1.224)$ \\
Forced Turnover & -1.941 \\
& $(-1.972)^{*}$ \\
Adjusted $\mathrm{R}^{2}$ & 6.265 \\
(F) & $(4.203)^{* * *}$ \\
$\mathrm{~N}$ & $8.8 \%$ \\
& $(10.432)^{* * *}$ \\
White-Koenker & 661 \\
\end{tabular}

$* * *$ Significant at $0.001,{ }^{* *}$ Significant at $0.01, *$ Significant at $0.05, \dagger$ Significant at 0.10

Instrumental variable:

"Average Age of New Director Appointment" is the average age of newly appointed directors in the year of succession (using data from the Roster of New Director Appointments in appropriate issues of Directors and Boards).

Dependent variables:

" $\triangle$ CEO Age" is the difference between the new and old CEO age.

Independent variables:

" $\triangle$ Average Board Age" is the difference between the average age of the board members in year +1 and year -1 . "Ind. Adj. ROA ( $t=-1$ to-3)" is the firm's industry adjusted ROA from year-1 to -3 aggregate. "Ln Total Assets ( $t=-1$ to-3)" is the natural $\log$ of the total assets of the firm from year-1 to -3 aggregate. "Designated Heir" is equal to1 if the new inside CEO was the designated heir apparent and equal to 0 otherwise. "Insider Successor" is equal to 1 for inside successor and equal to 0 for outside successor. "Forced Turnover" is equal to 1 for forced turnover and equal to 0 for voluntary turnover. We also control for time with annual year dummy variables. For example: " $1993 \mathrm{D}=1$ " is equal to 1 for successions that occur in 1993 and equal to 0 otherwise, " $1994 \mathrm{D}=1$ " is equal to 1 for successions that occur in 1994 and equal to 0 otherwise, etc. 
Table 2. 2SLS Estimates for Hypothesis 2: Change in risk is a negative function of the change in CEO age ( $\mathrm{t}$ statistics in brackets)

\begin{tabular}{cc}
\hline & Std Dev of Cash Flows \\
& $(\mathrm{t}=-3)$ \\
\hline Constant & 1.986 \\
& $(0.642)$ \\
CEO Age & -0.010 \\
& $(-2.228)^{*}$ \\
Ind. Adj. ROA ( $\mathrm{t}=-3$ to-1) & -0.022 \\
& $-1.817) \dagger$ \\
Ln Total Assets ( $\mathrm{t}=-3$ to- 1$)$ & -0.276 \\
& $(-1.301)$ \\
Designated Heir & -0.913 \\
& $(-1.120)$ \\
Insider Successor & 1.221 \\
& $(1.248)$ \\
Forced Turnover & -0.295 \\
New CEO Horizon & $(-0.207)$ \\
& 0.003 \\
$\Delta$ Variable Pay to Fixed Pay & $(0.048)$ \\
(t-1 to +1$)$ & -0.022 \\
Adjusted $\mathrm{R}^{2}$ & $(-0.407)$ \\
(F) & $3.5 \%$ \\
$\mathrm{~N}$ & $(1.606) \dagger$ \\
& 309 \\
White-Koenker & 24.317 \\
\hline
\end{tabular}

*** Significant at $0.001, * *$ Significant at $0.01, *$ Significant at $0.05, \uparrow$ Significant at 0.10

Instrumental variable:

"Average CEO Age in Fortune 500 Firms" is the average age of the CEOs in the Fortune 500 firms for each year in our study.

Dependent variables:

"Std. Dev. Of Cash Flows ( $\mathrm{t}=-3)$ " is the standard deviation of cash flows for the three years prior to the succession. Independent variables:

" $\triangle$ CEO Age" is the difference between the new and old CEO age. "Ind. Adj. ROA ( $t=-1$ to-3)" is the firm's industry adjusted ROA from year-1 to -3 aggregate. "Ln Total Assets ( $t=-1$ to-3)" is the natural log of the total assets of the firm from year-1 to -3 aggregate. "Designated Heir" is equal to 1 if the new inside CEO was the designated heir apparent and equal to 0 otherwise. "Insider Successor" is equal to 1 for inside successor and equal to 0 for outside successor. "Forced Turnover" is equal to 1 for forced turnover and equal to 0 for voluntary turnover. "New CEO Horizon" is the difference between 65 and the new CEO age. " $\Delta$ Variable Pay to Fixed Pay $(\mathrm{t}-1$ to +1$)$ " is the difference between variable pay to fixed pay in years +1 and -1 . We also control for time with annual year dummy variables. For example: " $1993 \mathrm{D}=1$ " is equal to 1 for successions that occur in 1993 and equal to 0 otherwise, " $1994 \mathrm{D}=1$ " is equal to 1 for successions that occur in 1994 and equal to 0 otherwise, etc. 